] O U R A L O F

French and Francophone Philosophy
REV VUE DE LA

philosophie française et de langue française

\title{
Introduction: 75 Years Later
}

\author{
Mark William Westmoreland
}

Journal of French and Francophone Philosophy - Revue de la philosophie française et de langue française, Vol XXIV, No 2 (2016) 1-2.

\author{
Vol XXIV, No 2 (2016) \\ ISSN 1936-6280 (print) \\ ISSN 2155-1162 (online) \\ DOI $10.5195 /$ jffp. 2016.766 \\ www.jffp.org
}

\section{(c) EY-NC-ND}

This work is licensed under a Creative Commons Attribution-Noncommercial-No Derivative Works 3.0 United States License.

\section{ULIS D-Surtol}

This journal is operated by the University Library System of the University of Pittsburgh as part of its D-Scribe Digital Publishing Program, and is co-sponsored by the University of Pittsburgh Press 


\section{Introduction}

\section{Years Later}

\section{Mark William Westmoreland \\ Villanova University}

This special issue of the Journal of French and Francophone Philosophy / Revue de la philosophie française et de langue française commemorates the $75^{\text {th }}$ anniversary of the death of French philosopher Henri Bergson (1859-1941). Bergson was unique in that he offered a vibrant metaphysics at a time when philosophy was dominated by neo-Kantianism and the rise of so-called analytic philosophy. According to William James, Bergsonism revealed itself to be the next Copernican revolution in philosophy - a philosophical reversal of the Kantian erasure of metaphysics. It has been noted by many, such as Suzanne Guerlac and Leonard Lawlor, that a resurgence of Bergsonism is largely due to interest in the philosophy of Gilles Deleuze, who, throughout his oeuvre shows a profound sense of indebtedness to Bergson. Like Deleuze, in this issue, we hope to honor the philosophical legacy of Bergson and Bergsonism.

The essays in this special issue speak to a wide variety of philosophical ideas and themes that one can find throughout Bergson's writings. Perhaps one could divide the issue into three sections: politics and ethics, metaphysics and epistemology, and art. Readers will appreciate the extent to which the essays explore Bergson's connections with other thinkers such as Kant, Guyau, Nietzsche, Adorno, Canguilhem, and Cassirer. Furthermore, quite often, one essay will overlap one or more other essays. For example, Alexandre Lefebvre, Adriana Alfaro Altamirano, and Anthony Paul Smith discuss The Two Sources on Morality and Religion and Keith Ansell-Pearson and Messay Kebede explore dimensions of Creative Evolution. Donna Jones and Iris Van der Tuin among others consider the reception history of Bergson's philosophy. The essays, nevertheless, stand alone as self-contained units. Furthermore, while the essays are arranged according to thematic overtones, the reader should feel at liberty to read the essays in any order one so chooses.

This special issue begins with a translation by Lawlor of Henri Bergson's speech "Politeness." The essay by Jones historically contextualizes Bergson's philosophy in light of his experience of World War I and the reasons 
why Bergson became concerned with the ways in which his vitalism might have had political consequences. Lefebvre continues this line of inquiry by exploring how a Bergsonian notion of human rights allows us to think of rights as means for self-care. Alfaro Altamirano, by integrating Bergson and Guyau, connects ethical and metaphysical dimensions of Bergson's philosophy by demonstrating how one's sense of obligation and capacity for action are connecting one's relation to uncertainty. The next two essays shed light on the originality of Bergson's philosophy. Camille Riquier, whose essay is translated by Erik Beranek, explains how Bergson might be thought to have overcome the Kantian critique with a new kind of metaphysics. In a similar vein, Keith Ansell-Pearson describes how Bergson reformed philosophy through his challenge against mechanistic thinking and his appreciation of the evolution of life. Kebede returns to a major debate in the scholarship on Bergson, namely the extent to which Bergson was a monist or dualist, by contrasting Bergson with Nietzsche. According to Kebede, Creative Evolution provides a diagonal approach to Being that circumvents the false binary of monism/dualism. The essay by Smith, who inaugurates a series of essays that deal with critical engagements with Bergson (in this case, Adorno), replaces the monism/dualism binary in his radical understanding of evil by giving attention to the dualism of the mechanical and the mystical that also runs throughout the Two Sources. Alex Feldman and Van der Tuin place Bergson in conversation with Canguilhem and Cassirer, respectively. Van der Tuin also orients us towards a Bergsonian approach to art through the lens of Susanne K. Langer. In the final essay, John Ó Maoilearca offers a way of thinking about art by placing Bergson's cinematic model in conversation with Lars von Trier's approach to film-making.

The special issue concludes with a distinctive contribution: Bergson(ism) Remembered: A Roundtable, which I curated with Brien Karas. The roundtable features contributions from Jimena Canales, Stephen Crocker, Souleymane Bachir Diagne, Michael Foley, Hisashi Fujita, Suzanne Guerlac, Melissa McMahon, Charlotte de Mille, Paulina Ochoa Espejo, and Frédéric Worms.

Lastly, much appreciation is warranted for the editors of JFFP for including an issue devoted solely to Bergson(ism). I want to thank Eddy Souffrant for helping me with French sources. I also am grateful for Len Lawlor's assistance at various stages along the way. And finally, I offer warm hugs and thanks to Laura, Brynne, and Adeline. 